\title{
MOTOR SKILLS IN PHYSICAL FITNESS STRUCTURE OF 8-YEAR-OLD GIRLS
}

\author{
Taisiia Shevchenko ${ }^{1 \mathrm{ABCD}}$, Oleg Khudoliii ${ }^{1 \mathrm{ABCD}}$, Vladimir Potop ${ }^{2 \mathrm{ABCD}}$
}

${ }^{1}$ H. S. Skovoroda Kharkiv National Pedagogical University

${ }^{2}$ Ecological University of Bucharest

Authors' Contribution: A - Study design; B - Data collection; C - Statistical analysis; D - Manuscript Preparation; E - Funds Collection

DOI: $10.17309 / \mathrm{jltm} .2020 .2 .03$

\begin{abstract}
The purpose of the study was to determine the priority of motor skills in the motor fitness structure of 8-year-old girls.

Materials and methods. The study participants were 40 8-year-old girls. The children and their parents were informed about all the features of the study and gave their consent to participate in the experiment. The study used the following research methods: analysis of scientific and methodological literature, pedagogical observations, testing of motor fitness, probabilistic approach to assessing the learning process, methods of mathematical statistics. In the experiment, the study controlled the level of proficiency in the following exercises: "Shoulder stand", "Bridge from supine position", "One leg swing upward circle".

Results. The level of fitness of the 8-year-old girls is homogeneous by the development of "agility", "movement coordination", "speed strength", and "endurance"; inhomogeneous - by the development of flexibility, arm strength, vestibular stability, and the level of proficiency.

The most informative indicators that determine the level of the 8-year-old girls' motor fitness are: No. 14 "One leg swing upward circle, level of proficiency" ( $r=0.890)$; No. 7 "Mixed hang rope pull-ups, times" $(r=0.889)$; No. 13 "Bridge from supine position, level of proficiency" ( $r=0.842)$.

Conclusions. Based on factor analysis, it was found that the level of proficiency in exercises influences the variation of testing results, and the development of motor skills is a priority in the educational process at primary school.

The level of proficiency in the exercises "Shoulder stand" and "One leg swing upward circle" shows that the exercises are difficult for 8-year-old girls to perform. Based on the data analysis, it can be argued that the comprehensive development of motor abilities ensures the formation of motor skills, and the improvement of the level of development of 8-year-old girls' arm flexors and vestibular stability will positively influence the educational process effectiveness.

Keywords: 8-year-old girls, motor skills, motor abilities, factor analysis.
\end{abstract}

\section{Introduction}

The studies by Krutsevych (2012), Krutsevych, Napadii, and Trachuk (2014) elaborated on the concept of improving secondary school physical education programs and periodizing schoolchildren's physical training in the educational process.

Particular attention is paid to the physical education of primary schoolchildren (Krivolapchuk \& Chernova, 2019; Ivashchenko, 2020; Khudolii, Iermakov, \& Bartik, 2020). Studies considered the issues of children's age-related development (Krivolapchuk, Chernova, \& Gerasimova, 2020); Krivolapchuk, Gerasimova, Myshiakov, \& Chicherin, 2020), learning process (Khudolii, Ivashchenko, \& Chernenko, 2013; Khudolii, \& Chernenko, 2013), motor abilities development

(C) Shevchenko, T., Khudolii, O., Potop, V., 2020.
(Chernenko, 2009; Titarenko, 2010; Khudolii \& Titarenko, 2012).

However, further research is needed to determine the priority of motor skills development in the primary school educational environment.

The purpose of the study was to determine the priority of motor skills in the motor fitness structure of 8-year-old girls.

\section{Materials and Methods}

\section{Study Participants}

The study participants were 408 -year-old girls. The children and their parents were informed about all the features of the study and gave their consent to participate in the experiment. 


\section{Organization of the Study}

The study used the following research methods: analysis of scientific and methodological literature, pedagogical observations, testing of motor fitness, probabilistic approach to assessing the learning process, methods of mathematical statistics.

The study recorded the indicators of height $(\mathrm{cm})$, body weight $(\mathrm{kg})$, and the results in tests No. 3 "Standing long jump, cm", No. 4 "Middle- and long-distance running. 300 $\mathrm{m}$ running, s", No. 5 "30 m sprint running from a standing start, s", No. 6 "Seated forward bend, cm", No. 7 "Mixed hang rope pull-ups, times", No. 8 "Shuttle run $4 \times 9$ m, s", No. 9 "Combined movements of arms, torso and legs, points", No. 10 "Maintenance of stable posture - standing on one leg with closed eyes, s", No. 11 "Walking along straight line after 5 rotations, deviations in cm".

The study recorded the primary schoolchildren's level of proficiency in gymnastic exercises. The coefficient was determined by the formula: $\mathrm{p}=(\mathrm{m} / \mathrm{n}) \times 100$, where $\mathrm{p}$ is the level of proficiency, $\mathrm{m}$ is the number of successfully performed exercises, $\mathrm{n}$ is the total number of attempts to perform the exercise. In the experiment, the study controlled the level of proficiency in the following exercises: "Shoulder stand", "Bridge from supine position", "One leg swing upward circle".

\section{Statistical Analysis}

The study materials were processed using the IBM SPSS 20 statistical analysis software. Factor analysis was performed. In the factor analysis, the study used the model of principal components with the rotation method: Varimax with Kaiser Normalization.

The study protocol was approved by the Ethical Committee of the University. In addition, the children and their parents or legal guardians were fully informed about all the features of the study, and a signed informed-consent document was obtained from all the parents.

\section{Results}

Table 1 shows the results of testing the 8-year-old girls' motor fitness.

The analysis of the coefficients of variation of testing results showed that the 8-year-old girls' fitness is homogeneous by the following tests: No. 1 "Height, cm" (3.86\%); No. 8 "Shuttle run $4 \times 9 \mathrm{~m}, \mathrm{~s}$ " (4.76\%); No. 5 "30 m running from a standing start, s" (6.36\%); No. 9 "Combined movements of arms, torso and legs, points" (7.87\%); No. 4 "300 m running, s" (11.08\%); No. 3 "Standing long jump, cm" (11.51\%); No. 2 "Body weight, kg" (16.71\%); No. 13 "Bridge from supine position, level of proficiency" (25.67\%).

The level of the girls' fitness is inhomogeneous by the results of tests: No. 6 "Seated forward bend, cm" (55.42\%); No. 10 "Maintenance of stable posture - standing on one leg with closed eyes, s" (71.57\%); No. 7 "Mixed hang rope pull-ups, times" (61.54\%); No. 11 "Walking along straight line after 5 rotations, deviations in cm" (89.25\%); No. 12 "Shoulder stand, level of proficiency" (41.29\%); No. 14 "One leg swing upward circle, level of proficiency” (80.89\%).

The coefficient of variation in terms of the level of proficiency in the exercises "Shoulder stand, level of proficiency"
Table 1. The results of testing the 8-year-old girls' motor fitness $(n=40)$

\begin{tabular}{llcrr}
\hline No. & \multicolumn{1}{c}{ Indicator } & \multicolumn{1}{c}{ s } & \multicolumn{1}{c}{ V, \% } \\
\hline 1 & Height, cm & 127.1 & 4.9 & 3.86 \\
2 & Body weight, kg & 26.93 & 4.5 & 16.71 \\
3 & Standing long jump, cm & 116.4 & 13.4 & 11.51 \\
4 & 300 m running, s & 130.02 & 14.4 & 11.08 \\
5 & 30 m running from a standing & 6.6 & 0.42 & 6.36 \\
& start, s & & & \\
6 & Seated forward bend, cm & 8.3 & 4.6 & 55.42 \\
7 & Mixed hang rope pull-ups, times & 2.6 & 1.6 & 61.54 \\
8 & Shuttle run 4×9 m, s & 12.6 & 0.6 & 4.76 \\
9 & Combined movements of arms, & 8.9 & 0.7 & 7.87 \\
& torso and legs, points & & & \\
10 & Maintenance of stable posture - & 20.4 & 14.6 & 71.57 \\
& standing on one leg with closed & & & \\
$\quad$ eyes, s & & & \\
11 & Walking along straight line after 5 & 96.7 & 86.3 & 89.25 \\
& rotations, deviations in cm & & & \\
12 & Shoulder stand, level of proficiency & 49.0 & 20.23 & 41.29 \\
13 & Bridge from supine position, & 61.0 & 15.66 & 25.67 \\
& level of proficiency & & & \\
14 & One leg swing upward circle, & 32.5 & 26.29 & 80.89 \\
& level of proficiency & & & \\
\hline
\end{tabular}

and "One leg swing upward circle, level of proficiency" shows that the exercises are difficult to perform.

Thus, the level of fitness of the 8-year-old girls is homogeneous by the development of "agility", "movement coordination", "speed strength", and "endurance"; inhomogeneous - by the development of flexibility, arm strength, vestibular stability, and the level of proficiency.

Table 2 shows the results of factor analysis. The analysis identified five factors that explain $74.253 \%$ of the variation of results.

The first factor has a weight of $16.411 \%$. With the factor, the greatest correlation is in the level of proficiency in exercise No. 14 "One leg swing upward circle, level of proficiency" $(\mathrm{r}=0.640)$; tests No. 7 "Mixed hang rope pull-ups, times" ( $\mathrm{r}=$ $0.721)$; No. 3 "Standing long jump, $\mathrm{cm}$ " $(\mathrm{r}=0.716)$. The factor is called the level of proficiency in gymnastic exercises that require a complex demonstration of strength.

The second factor has a weight of $15.359 \%$. With the factor, the greatest correlation is in: No. 12 "Shoulder stand, level of proficiency" ( $r=-0.733)$; No. 11 "Walking along straight line after 5 rotations, deviations in $\mathrm{cm}$ " ( $\mathrm{r}=0.811)$. The factor is bipolar, on the one hand, the lower the level of proficiency, the greater the influence of the factor; on the other - reducing the error in vestibular stability reduces the influence of the factor, which points to the influence of vestibular stability on the level of proficiency in acrobatic exercises. The factor is called vestibular stability.

The third factor has a weight of $15.252 \%$. With the factor, the greatest correlation is in: No. 1 "Height, $\mathrm{cm}$ " $(\mathrm{r}=0.581)$; No. 2 "Body weight, kg" ( $\mathrm{r}=0.609)$; No. 4 "300 m running, $\mathrm{s}$ " $(r=0.630)$. The factor is called physical development.

The fourth factor has a weight of $14.694 \%$. With the factor, the greatest correlation is in: No. 7 "Mixed hang rope pull-ups, times" ( $\mathrm{r}=0.566)$; No.14 "One leg swing upward circle, level of proficiency" ( $r=0.510)$. The factor is called strength fitness.

The fifth factor has a weight of $12.537 \%$. With the factor, the greatest correlation is in test: No. 10 "Maintenance of 
Table 2. The results of factor analysis. Girls aged $8(n=40)$

\begin{tabular}{|c|c|c|c|c|c|c|c|}
\hline \multirow{2}{*}{ No. } & \multirow{2}{*}{ Indicator } & \multicolumn{5}{|c|}{ Component } & \multirow{2}{*}{$\mathbf{h}^{2}$} \\
\hline & & 1 & 2 & 3 & 4 & 5 & \\
\hline$\overline{1}$ & Height, $\mathrm{cm}$ & -0.445 & & 0.581 & 0.393 & & 0.805 \\
\hline 2 & Body weight, $\mathrm{kg}$ & -0.587 & & 0.609 & & & 0.774 \\
\hline 3 & Standing long jump, $\mathrm{cm}$ & 0.716 & & & & & 0.660 \\
\hline 4 & $300 \mathrm{~m}$ running, $\mathrm{s}$ & & 0.359 & 0.630 & & 0.406 & 0.780 \\
\hline 5 & $30 \mathrm{~m}$ running from a standing start, $\mathrm{s}$ & & & 0.415 & -0.493 & 0.454 & 0.722 \\
\hline 6 & Seated forward bend, $\mathrm{cm}$ & 0.534 & 0.380 & 0.458 & & -0.435 & 0.834 \\
\hline 7 & Mixed hang rope pull-ups, times & 0.721 & & & 0.566 & & 0.889 \\
\hline 8 & Shuttle run $4 \times 9 \mathrm{~m}, \mathrm{~s}$ & -0.598 & & & 0.315 & 0.331 & 0.604 \\
\hline 9 & Combined movements of arms, torso and legs, points & & & & -0.627 & & 0.513 \\
\hline 10 & Maintenance of stable posture - standing on one leg with closed eyes, $s$ & & -0.399 & & -0.368 & -0.538 & 0.601 \\
\hline 11 & Walking along straight line after 5 rotations, deviations in $\mathrm{cm}$ & & 0.811 & & & & 0.720 \\
\hline 12 & Shoulder stand, level of proficiency & & -0.733 & 0.464 & & & 0.762 \\
\hline 13 & Bridge from supine position, level of proficiency & 0.496 & 0.546 & 0.362 & & -0.372 & 0.842 \\
\hline 14 & One leg swing upward circle, level of proficiency & 0.640 & -0.327 & & 0.510 & 0.331 & 0.890 \\
\hline & $\%$ & 16.411 & 15.359 & 15.252 & 14.694 & 12.537 & 74.253 \\
\hline
\end{tabular}

stable posture - standing on one leg with closed eyes, s" ( $\mathrm{r}=$ -0.538). The factor is called vestibular stability.

The analysis of similarities made it possible to identify the most informative indicators that determine the level of motor fitness of the 8-year-old girls:

No.14 "One leg swing upward circle, level of proficiency" $(\mathrm{r}=0.890)$;

No. 7 "Mixed hang rope pull-ups, times" ( $\mathrm{r}=0.889$ );

No. 13 "Bridge from supine position, level of proficiency" $(\mathrm{r}=0.842)$.

The graphic representation of a two-factor model of testing results shows that the analysis identifies two sets of data with high correlation coefficients. The first set includes tests No. 14, 3, and 7, which characterize the level of proficiency in gymnastic exercises, speed and relative strength; the second one includes tests No. 11, 12, and 13, which characterize vestibular stability and the level of proficiency in gymnastic exercises (see Fig. 1).

Thus, the 8-year-old girls' motor fitness is determined, on the one hand, by the level of development of arm strength and the level of proficiency in strength gymnastic exercises; on the other hand, by vestibular stability and the level of proficiency in acrobatic exercises.

\section{Discussion}

The paper assumed that motor skills occupy a leading place in the motor fitness structure of 8-year-old girls. So, the level of proficiency in exercises determines the variation of testing results by $16.411 \%$. Thus, the study's findings make it possible to accept the research hypothesis on the leading role of motor skills development in physical education classes at primary school.

The analysis of the coefficients of variation points to heterochrony in the development of the 8-year-old girls' motor abilities. The level of proficiency in exercises No. 12 and 14 indicates that the exercises are difficult for 8-year-old girls to perform. Based on the data analysis, it can be argued that the comprehensive development of motor abilities ensures the formation of motor skills, and the improvement of the level of development of 8-year-old girls' arm flexors and vestibu-

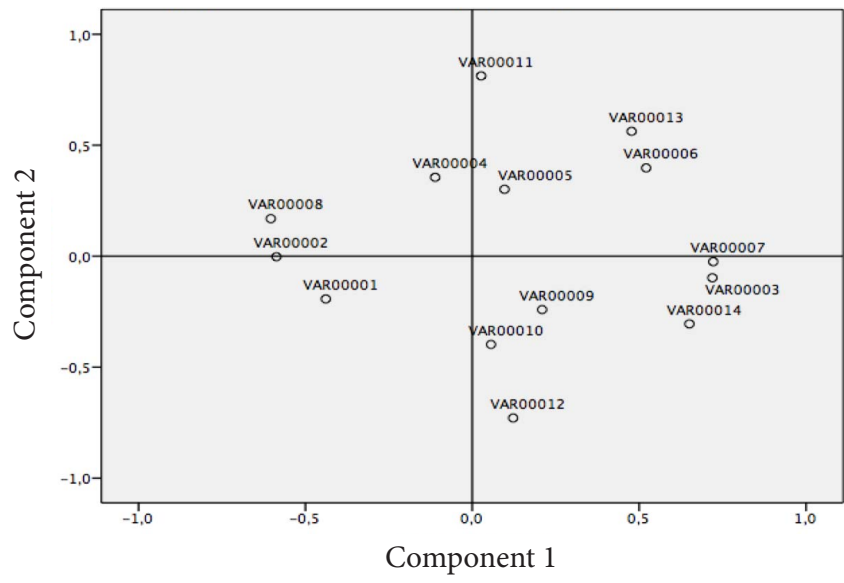

Fig. 1. The graphic representation of a two-factor model of testing results: 1 - height $(\mathrm{cm}), 2$ - body weight $(\mathrm{kg}), 3$ - "Standing long jump (cm)", 4 - "Middle- and long-distance running. $300 \mathrm{~m}$ running (s)", 5 - "30 m sprint running from a standing start (s)", 6 - "Seated forward bend $(\mathrm{cm})$ ", 7 - "Mixed hang rope pull-ups (times)", 8 - "Shuttle run $4 \times 9 \mathrm{~m}$ (s)", 9 - "Combined movements of arms, torso and legs (points)", 10 - "Maintenance of stable posture - standing on one leg with closed eyes (s)", 11 - "Walking along straight line after 5 rotations (deviations in $\mathrm{cm}$ )", 12 - "Shoulder stand, level of proficiency", 13 - "Bridge from supine position, level of proficiency", 14 - "One leg swing upward circle, level of proficiency"

lar stability will positively influence the educational process effectiveness.

The obtained results supplement the data on the relationship between the level of proficiency in gymnastic exercises and the level of development of strength and vestibular stability (Ivashchenko, Berezhna, \& Cieślicka, 2020; Ivashchenko \& Sirichenko, 2020). As with 7-year-old girls, there is considerable variation in the development of flexibility, arm strength, and vestibular stability. Similarly, based on factor analysis, it was found that the level of proficiency in exercises affects the variation of testing results, and the development of motor skills is a priority in the educational process at primary school; the development of vestibular stability ensures the formation of motor skills, and the level of general physi- 
cal fitness is the reserve in training 7-year-old girls that will improve the educational process effectiveness (Ivashchenko \& Sirichenko, 2020).

The results of factor analysis confirm the integrity of the process of motor skills formation and motor abilities development in children, give the opportunity to determine the direction of motor abilities development (Khudolii, Ivashchenko, \& Chernenko, 2015; Ivashchenko, Iermakov, Khudolii, Cretu, \& Potop, 2017).

The results of the study highlight the need to develop a teaching technique which would include the development of motor abilities and series of learning tasks (Ivashchenko, Khudolii, Iermakov, Chernenko, \& Holovko, 2015), organization of a series of classes (Hellin, Garcia-Jimenez, \& Garcia-Pellicer, 2019a; Hellin, Garcia-Jimenez, \& Garcia-Pellicer, 2019b; Groffik, Mitáš, Jakubec, Svozil, \& Frömel, 2020), and modes of alternating exercises and rest intervals (Ivashchenko \& Cieślicka, 2017; Cieślicka \& Ivashchenko, 2017; Marchenko \& Kovalenko, 2020).

Thus, the 8-year-old girls' motor fitness is determined, on the one hand, by the level of development of arm strength and the level of proficiency in strength gymnastic exercises; on the other hand, by vestibular stability and the level of proficiency in acrobatic exercises.

\section{Conclusions}

Based on factor analysis, it was found that the level of proficiency in exercises influences the variation of testing results, and the development of motor skills is a priority in the educational process at primary school.

The level of proficiency in the exercises "Shoulder stand" and "One leg swing upward circle" shows that the exercises are difficult for 8-year-old girls to perform. Based on the data analysis, it can be argued that the comprehensive development of motor abilities ensures the formation of motor skills, and the improvement of the level of development of 8-yearold girls' arm flexors and vestibular stability will positively influence the educational process effectiveness.

\section{Acknowledgement}

The study was carried out in accordance with the plan of research work of the Department of Theory and Methodology of Physical Education of H. S. Skovoroda Kharkiv National Pedagogical University.

\section{Conflict of Interests}

The authors declare no conflicts of interest.

\section{References}

Krutsevych, T. Yu. (2012). Kontseptsiia udoskonalennia prohram z fizychnoi kultury u zahalnoosvitnii shkoli. Fizychne vykhovannia $v$ suchasnii shkoli, 2(78), 8-9.

Krutsevych, T., Napadii, A., \& Trachuk, S. (2014). Periodyzatsiia fizychnoi pidhotovky shkoliariv v umovakh navchalnoho protsesu. Sportyvnyi visnyk Prydniprovia, (1), 60-67.
Krivolapchuk, I. A., \& Chernova, M. B. (2019). Peculiarities of the Factorial Structure of the Functional State in Children Aged 9-10 Years. Human Physiology, 45(1), 30-39. Scopus. https://doi.org/10.1134/S0362119718050067

Ivashchenko, O. (2020). Research Program: Modeling of Motor Abilities Development and Teaching of Schoolchildren. Teoriâ ta Metodika Fizičnogo Vihovannâ, 20(1), 32-41. https://doi.org/10.17309/tmfv.2020.1.05

Khudolii, O., Iermakov, S., \& Bartik, P. (2020). Didactics: Methodological Basis of Motor Learning in Children and Adolescents. Journal of Learning Theory and Methodology, 1(1), 5-13. https://doi.org/10.17309/jltm.2020.1.01

Krivolapchuk, I. A., Chernova, M. B., \& Gerasimova, A. A. (2020). Effect of regular physical activity of various intensity on the functional status of 5-6 and 6-7-year-old children. Human Sport Medicine, 20(2), 71-79. Scopus. https://doi.org/10.14529/HSM200209

Krivolapchuk, I. A., Gerasimova, A. A., Myshiakov, V. V., \& Chicherin, V. P. (2020). The effect of anaerobic glycolytic performance on the functional status and cognitive efficiency in primary schoolchildren. Human Sport Medicine, 19(2), 29-36. Scopus. https://doi.org/10.14529/HSM19S204

Khudolii, O., Ivashchenko, O., \& Chernenko, S. (2013). Factors that influence on efficiency of educating to physical exercises of girls of junior classes. Teoriâ ta Metodika Fìzičnogo Vihovannâ, (2), 43-47. https://doi.org/10.17309/tmfv.2013.2.1016

Khudolii, O., \& Chernenko, S. (2013). Features of forming of motive skills for the schoolchildren of junior classes. Teoriâ ta Metodika Fizičnogo Vihovannâ, (3), 13-21. https://doi.org/10.17309/tmfv.2013.3.1021

Chernenko, S. (2009). Osoblyvosti fizychnoho rozvytku divchatok 6-10 rokiv. Teoriâ ta Metodika Fizičnogo Vihovannâ, (6), 32-34.

Retrieved from https://tmfv.com.ua/journal/article/view/540

Khudolii, O., \& Titarenko, A. (2012). Osoblyvosti metodyky rozvytku syly u divchatok molodshoho shkilnoho viku. Teoriâ ta Metodika Fizičnogo Vihovannâ, (2), 3-18, 35. https://doi.org/10.17309/tmfv.2012.2.767

Titarenko, A. (2010). Osoblyvosti rozvytku rukhovykh zdibnostei u divchatok molodshoho shkilnoho viku. Teoriâ ta Metodika Fizičnogo Vihovannâ, (9), 3-13. Retrieved from https://tmfv.com.ua/journal/article/view/652

Ivashchenko, O., Berezhna, H., \& Cieślicka, M. (2020). Motor Skills in the Structure of Physical Fitness of 7-Year-Old Boys. Journal of Learning Theory and Methodology, 1(1), 14-19. https://doi.org/10.17309/jltm.2020.1.02

Ivashchenko, O., \& Sirichenko, D. (2020). Structure of Motor Fitness of 7-Year-Old Girls. Journal of Learning Theory and Methodology, 1(1), 20-25. (in Ukrainian) https://doi.org/10.17309/jltm.2020.1.03

Marchenko, S., \& Kovalenko, K. (2020). Optimization of Teaching Boys Aged 10 Mae-Geri (Front Kick) Technique in Kyokushin Karate. Journal of Learning Theory and Methodology, 1(1), 33-39. (in Ukrainian) https://doi.org/10.17309/jltm.2020.1.05

Ivashchenko, O., Khudolii, O., Iermakov, S., Chernenko, S., \& Holovko, A. (2015). Pedagogical Control of Motor Readiness of Junior School Boys. Teoriâ ta Metodika 
Fizičnogo Vihovannâ, (2), 32-40. (in Ukrainian) https://doi.org/10.17309/tmfv.2015.2.1140

Ivashchenko, O., Iermakov, S., Khudolii, O., Cretu, M., \& Potop, V. (2017). Level of physical exercises' mastering in structure of 11-13 yrs age boys' motor fitness. Pedagogics, Psychology, Medical-Biological Problems of Physical Training and Sports, 21(5), 236-243. https://doi.org/10.15561/18189172.2017.0506

Khudolii, O., Ivashchenko, O., \& Chernenko, S. (2015). Simulation of junior shcoolchildren's training to acrobatic exercises and vaults. Pedagogics, Psychology, MedicalBiological Problems of Physical Training and Sports, 19(7), 64-71. https://doi.org/10.15561/18189172.2015.0709

Ivashchenko, O., \& Cieślicka, M. (2017). Features of evaluations of power loadsin boys 7 years old. Journal of Education, Health and Sport, 7(1), 175-183. http://dx.doi.org/10.5281/zenodo.249184

Cieślicka, M., \& Ivashchenko, O. (2017). Features of formation of the cumulative effect of power loads in boys 7 years old. Journal of Education, Health and Sport, 7(1), 198-208. http://dx.doi.org/10.5281/zenodo.250599
Hellin, M., Garcia-Jimenez, J. V., \& Garcia-Pellicer, J. J. (2019a). Intensity of physical education lessons in children according to the type of activity: Soccer, badminton, aerobics and motor skills. Journal of Physical Education and Sport, 19(1), 603-610. Scopus. https://doi.org/10.7752/jpes.2019.01088

Hellin, M., Garcia-Jimenez, J. V., \& Garcia-Pellicer, J. J. (2019b). Intensity of physical education lessons in children according to the type of activity: Soccer, badminton, aerobics and motor skills. Journal of Physical Education and Sport, 19, 148-155. Scopus. https://doi.org/10.7752/jpes.2019.s1022

Groffik, D., Mitáš, J., Jakubec, L., Svozil, Z., \& Frömel, K. (2020). Adolescents' Physical Activity in Education Systems Varying in the Number of Weekly Physical Education Lessons. Research Quarterly for Exercise and Sport. Scopus. https://doi.org/10.1080/02701367.2019.1688754

\title{
РУХОВІ НАВИЧКИ У СТРУКТУРІ ФІЗИЧНОї ПІДГОТОВЛЕНОСТІ ДІВЧАТОК 8 РОКІВ
}

\author{
Таїсія Шевченко $^{1 \mathrm{ABCD}}$, Олег Худолій ${ }^{1 \mathrm{ABCD}}$, Владімір Потоп ${ }^{2 \mathrm{ABCD}}$ \\ ${ }^{1}$ Харківський національний педагогічний університет імені Г. С. Сковороди \\ ${ }^{2}$ Екологічний університет Бухареста
}

Авторський вклад: А - дизайн дослідження; В - збір даних; C - статаналіз; D - підготовка рукопису; Е - збір коштів

Реферат. Статья: 6 с., 2 табл., 2 рис., 23 джерела.

Мета дослідження - визначити пріоритет рухових навичок у структурі рухової підготовленості дівчаток 8 років.

Матеріали і методи. У дослідженні прийняли участь 40 дівчаток 8 років. Діти та їхні батьки були інформовані про всі особливості дослідження і дали згоду на участь в експерименті. У дослідженні використані такі методи дослідження як аналіз наукової та методичної літератури, педагогічні спостереження, тестування рухової підготовленості, ймовірнісний підхід до оцінки процесу навчання, методи математичної статистики. В експерименті контролювався рівень навченості таким вправам: стійка на лопатках, міст із положення лежачи, підйом переворотом в упор махом однією.

Результати. За рівнем підготовленості дівчатка 8 років $\epsilon$ однорідними за розвитком «прудкості», «координації рухів», «швидкісної сили» та «витривалості», неоднорідними - за розвитком гнучкості, сили рук і вестибулярної стійкості, рівнем навченості.

Найбільш інформативними показниками, які визначають рівень рухової підготовленості дівчаток 8 років є:
No 14 «Підйом переворотом в упор махом однією, рівень навченості» ( $\mathrm{r}=0.890)$; No 7 «Згинання й розгинання рук у змішаному висі на канаті, рази» $(\mathrm{r}=0.889)$; No 13 «Міст із положення лежачи, рівень навченості» $(\mathrm{r}=0.842)$.

Висновки. На основі факторного аналізу встановлено, що рівень навченості вправам впливає на варіацію результатів тестування, а формування рухових навичок має пріорітет в освітньому процесі у молодшій школі.

Рівень навченості вправ «Стійка на лопатках» і «Підйом переворотом в упор махом однією» свідчить про те, що вправи $є$ малодоступними для дівчаток 8 років. На основі аналізу даних можна стверджувати, що комплексний розвиток рухових здібностей забезпечує формування рухових навчок, а підвищення рівня розвитку сили згиначів рук i вестибулярної стійкості у дівчаток 8 років дозволить позитивно впливати на ефективність навчального процесу.

Ключові слова: дівчатка 8 років, рухові навички, рухові здібності, факторний аналіз. 


\section{Information about the authors:}

Taisiia Shevchenko: taya.shevchenko.07@gmail.com; https://orcid.org/0000-0001-7695-2815; H. S. Skovoroda Kharkiv National Pedagogical University, Department of Theory and Methodology of Physical Education, Alchevskykh St, 29, Kharkiv, 61002, Ukraine.

Khudolii Oleg: khudoli@hnpu.edu.ua; http://orcid.org/0000-0002-5605-9939; H. S. Skovoroda Kharkiv National Pedagogical University, Department of Theory and Methodology of Physical Education, Alchevskykh St, 29, Kharkiv, 61002, Ukraine.

Potop Vladimir: vladimir_potop@yahoo.com; https://orcid.org/0000-0001-8571-2469; Dean of the Faculty of Physical education and sport, Ecological University of Bucharest, Bd.Vasile Milea nr. 1G, Sector 6, 061341 Bucuresti, Romania.

Cite this article as: Shevchenko, T., Khudolii, O., \& Potop, V. (2020). Motor Skills in Physical Fitness Structure of 8-Year-Old Girls. Journal of Learning Theory and Methodology, 1(2), 64-69. https://doi.org/10.17309/jltm.2020.2.03

Received: 27.08.2020. Accepted: 20.10.2020. Published: 30.10.2020

This work is licensed under a Creative Commons Attribution 4.0 International License (http://creativecommons.org/licenses/by/4.0). 